DOI: 10.34015/2523-4552.2019.2.16

УДК 343.8

Попельнюк Т. В., аспірант Східноєвропейського національного університету

імені Лесі Українки

\title{
ПРО КРИМІНОЛОГІЧНУ ХАРАКТЕРИСТИКУ ЗЛОЧИНІВ, ЩО ВЧИНЯЮТЬСЯ У СФЕРІ ВИКОНАННЯ ПОКАРАНЬ УКРАЇНИ
}

У статті здійснено кримінологічний аналіз злочинів, учинених в установах виконання покарань упродовж 1991-2018 років, а також визначено закономірності та тенденції, що склалися в цей період, які варто враховувати при організації запобіжної діяльності з цих питань.

Ключові слова: кримінологічна характеристика; засуджений; злочин; позбавлення волі; установа виконання покарань; запобігання злочинам; персонал кримінально-виконавчих установ.

В статье осуществлен криминологический анализ преступлений, совершенных в учреждениях по исполнению наказаний на протяжении 19912018 годов, а также установлены закономерности и тенденции, сложившиеся в этот период, которые следует учитывать в ходе организации профилактической деятельности по этим вопросам.

Ключевые слова: криминологическая характеристика; осужденный; преступление; лишения свободы; учреждения по исполнению наказаний; профилактика преступлений; персонал уголовно-исполнительных учреждений.

Постановка проблеми. Одним із завдань та, одночасно, елементів мети покарання в чинному кримінальному (частина перша статті 1 та частина друга статті 50 Кримінального кодексу [1] (далі - КК)) і кримінально-виконавчому (частина перша статті 1 та частина перша статті 104 Кримінально-виконавчого кодексу [2] (КВК)) законодавстві України визначено запобігання вчиненню злочинів як засудженими, так і іншими особами.

Проте з 1991 року до сьогодні щороку рівень злочинності у сфері виконання покарань України має стійкі тенденції до зростання (з 3,9 злочинів у розрахунку на 1 тис. засуджених у 1991 році [3, с. 1] до 4,91 - у 2016 році [4, с. 1-12]). При цьому однією з обставин, що негативно впливає на організацію діяльності із запобігання злочинам в установах виконання покарань (УВП), $є$ недостатнє інформаційне забезпечення цього процесу, в основі якого лежить кримінологічна характеристика злочинів, яка виведена на доктринальному рівні [5, с. 92-93] та має практичне значення. 
Постановка завдання. Отже, існує складна прикладна проблема, яка потребує невідкладного вирішення, у тому числі на науковому рівні, що й обумовило вибір теми цієї статті, а також визначено її головне завдання - довести необхідність більш активного та ефективного використання на практиці можливостей теоретичної моделі кримінологічної характеристики злочинів 3 метою вдосконалення правового механізму запобіжної діяльності у сфері виконання покарань України.

Аналіз останніх досліджень і публікацій. Вивчення наукової літератури засвідчило, що постійним предметом наукових досліджень $\epsilon$ кримінологічна характеристика в працях О. М. Бандурки, I. Г. Богатирьова, В. В. Василевича, В.В.Голіни, Б. М. Головіна, О. М. Джужі, Т. А. Денисової, О.Г. Колба, А. В. Савенка, В. О. Тулякова, В. І. Шакуна та інших учених.

Поряд із цим дані комплексного вивчення сфери виконання покарань через призму відомостей, що характеризують злочинність двох інтегрально протилежних систем (засуджених і персоналу УВП), у наукових джерелах не здійснено, хоча необхідність у цьому є очевидною, про що свідчать наведений вище аналіз статистичних даних злочинності за 1991-2016 роки.

Виклад основного матеріалу. Результати вивчення архівних матеріалів, які стосуються пенітенціарної злочинності в Україні упродовж 1991-2018 років, свідчать про те, що в змісті її кримінальної характеристики можна виокремити відомості, які $€$ однопорядковими та однотипними стосовно оцінки щорічно вчинених засудженими, які трималися в установах виконання покарань (далі - УВП), кримінальних правопорушень і фонових явищ, що обумовлювали ї здійснення вчиненими особами.

Прикладом цього $є$ дані про кількісно-якісні показники вчинення злочинів у кримінально-виконавчих установах (закритого та відкритого типу (частина третя статті 11 КВК)). Так, у 1991 році кримінологічна характеристика цих суспільно небезпечних діянь мала такий вигляд:

1) на кінець 1991 року кримінально-виконавча система України нараховувала 277 УВП, у яких відбували покарання понад 152 тис. засуджених, у тому числі 99 УВП з наповненням 94,5 тис. осіб, із них у жіночих - 3,4 тис. засуджених; 10 колонійпоселень - 3,2 тис. осіб; 4 колонії лікувального профілю 4,7 тис.); 11 виховних колоній - 3,4 тис. засуджених; 29 слідчих ізоляторів (СІ30) - 7,3 тис.; 95 спецкомендатур, у яких відбували покарання особи, засуджені до покарань, не пов'язаних з позбавленням волі [3, с. 1]. При цьому в 1991 році чисельність засуджених збільшилася на 3,2 тис. осіб, у зв'язку з чим відкрито дві УВП суворого режиму та дві колонії-поселення, а також виховну колонію $[3$, с. 1]. Майже на 3 тис. збільшилася кількість осіб, які тримались у СІ30. Водночас скорочення на $2 / 3$ чисельності осіб, які проходили примусовий курс лікування в лікувально-трудових профілакторіях, призвело до закриття та перепрофілювання 11 таких установ [3, c. 1];

2) упродовж 1991 року в системі УВП було вчинено 800 злочинів проти 1038 в 1990 році, або на 22,9\% менше [3, с. 1]. При цьому в колоніях злочинність скоротилася 3404 до 
370 випадків, а рівень злочинності знизився з 4,44 до 3,9 випадку з розрахунку на 1 тис. засуджених, або на $12,2 \%[3$, c. 1$]$;

3) структуру пенітенціарної злочинності у 1991 році склали: а) 16 убивств (на $25 \%$ більше, ніж у 1990 році); б) 34 тяжких тілесних ушкоджень; в) 2 злочини, пов'язані 3 діями, що дезорганізують роботу УВП; г) 20 злісних хуліганств; г) 48 втеч $з$ місць позбавлення волі (+ $37 \%)$ та інші злочини $[1$, с. 8$]$;

4) у 1991 році у виховних колоніях (один $з$ елементів «топографії» пенітенціарної злочинності [6, с. 6162]) кількість учинених неповнолітніми засудженими злочинів зросла на $58 \%$ (із 17 випадків у 1990 р. до 27 - у 1991 р.) [3, с. 2].

Структура цих злочинів мала такий вигляд: а) одне вбивство (Курязька колонія № 7 (елемент «географії» пенітенціарної злочинності); б) 7 тяжких тілесних ушкоджень (Курязька колонія № 7; Кременчуцька № 5; Бержанська № 6; Маріупольська виховна колонія № 4); в) 8 утеч 3 місць позбавлення волі (Курязська № 7, Кременчуцька № 5, Бережанська № 6, Ковельська виховна колонія № 3); г) 2 злісних хуліганства (Маріупольська № 4 та Ковельська виховна колонія № 4); г) інші злочини (Мелітопольська, Самбірська, Прилуцька - по одному, при цьому в Мелітопольській виховній колонії - замах на вбивство, а в Самбірській - замах на втечу) [3, с. 2];

5) у 1991 році (знову за топографічною ознакою кримінологічної характеристики) в CI30 і тюрмах пенітенціарна злочинність знизилася у 2,2 раза (з 33 випадків у 1990 р. до 15 - у 1991 р.). Поряд із цим у СІЗО Черкаської області допущено вбивство; в
CI30 Полтавської та Вінницької областей - по одному тяжкому тілесному ушкодженню, а в CI30 Дніпропетровської, Закарпатської, Луганської, Львівської та Чернівецької областей - по одній втечі [3, с. 3].

Так загалом виглядала пенітенціарна злочинність в УВП України на першому році їі незалежності та перебування органів і установ виконання покарань у складі МВС України з огляду кількісно-якісних її вимірів, що виведені на науковому рівні [6, c. 56-63] та апробовані на практиці [3].

Відомості, що склали зміст кримінологічної характеристики злочинів, учинених засудженими в УВП, отримані зі спеціального бюлетеня Головного управління виконання покарань МВС України, який вперше у 1991 році мав відкритий характер та був опублікований відповідно до Основних напрямів реформи кримінально-виконавчої системи в Українській РСР, що були затверджені постановою Кабінету Міністрів України від 14 липня 1991 року № 88 [7, c. 4]. При цьому варто зауважити, що в бюлетені були відсутні такі необхідні елементи кримінологічної характеристики, як інформація про особу злочинця та про причини i умови, які призвели до вчинення злочинів у сфері виконання покарань.

У 1998 році відповідно до Указу Президента України від 28 квітня 1998 року створено Державний департамент України з питань виконання покарань (ДДУПВП), який частково вивели 3 підпорядкування МВС України [8].

У зв'язку з цим теоретичну та практичну цінність становлять відомості про пенітенціарну злочинність 
за 1998 рік - останній період перебування органів та установ виконання покарань у системі МВС України, як показник своєрідних стартових позицій діяльності ДДУПВП з означених питань, ураховуючи те, що в 1991 -1997 роках кількісно-якісний показник злочинності у сфері виконання покарань суттєво не змінився [9, с. 22-26].

У свою чергу, у 1998 році кримінологічна характеристика злочинів, учинених засудженими в УВП, мала такий вигляд:

1) усього за цей період було зареєстровано 405 злочинів (у 1997 р. 525 , або на 22,3 \% більше, ніж у 1998 p.) [10, c. 16$]$;

2) 3 «топографічної» точки зору найбільша питома вага злочинів припадала на виправні колонії суворого (у структурі злочинності це склало 40,4 \% (порівняно з 1997 р. зростання на 9,7\%) та посиленого режиму $(30,6 \%(+11,7 \%))$;

3) щодо «географії злочинів», то найбільша їх кількість учинена у виправних колоніях суворого режиму в Донецькій (34 випадки), Вінницькій (30), Луганській (19) областях (у 1997 році до таких УВП були віднесені виправні колонії суворого режиму в Донецькій (37 злочинів), Вінницькій (26) та Луганській (24) областях) [10, с. 17];

4 у структурі пенітенціарної злочинності питома вага тяжких злочинів складала 4,4 \% (18 кримінальних справ із 405, порушених за фактами вчинення злочинів в УВП в 1998 році);

5) рівень злочинності в розрахунку на 1 тис. засуджених у 1998 році склав 276 випадків. При цьому в колоніях Вінницької області він зріс з 8,4 у 1997 р. до 9,6 - у
1998 р., Волинській - з 5,3 до 7,3; Кіровоградській - 3 7,2 до 8,3; Полтавській - з 3,2 до 3,8; Тернопільській - 3 2,5 до 3,3 випадків у розрахунку на 1 тис. засуджених [10, с. 17];

6) із 405 зареєстрованих злочинів 276 (68,1 \% у загальній їх кількості) вчинено засудженими в житлових зонах УВП (у 1997 р. - 328, або 62,5\%); 118 злочинів (29,1\%) - у виробничих зонах УВП та на виїзних об’єктах поза ними (1997 р. - 196, або 37,3 \%); 10 (2,5 \%) - у штрафних ізоляторах (ШІЗО) (у 1997 р. - один, або $0,2 \%)$; один злочин $(8,2 \%)$ - у приміщеннях камерного типу (ПКТ) (у 1997 р. - жодного) [10, с. 19] (це так званий «топографічний» аспект у змісті кримінологічної характеристики злочинів) [6, с. 61-62];

7) у 335 випадках $(82,7 \%$ у загальній структурі злочинності УВП) (у 1997 р. - 407 (77,5\%)) злочини вчинено з 06:00 до 18:00 або в період перебування в УВП найбільшої кількості персоналу установ; у 44 випадках $(10,9 \%)$ (у 1997 р. - 30 (17,2 \%)) кримінальні правопорушення вчинялися з 18:00 до 23:00, а в $26(6,4 \%)$ (у 1997 р. - $28(5,3 \%)$ ) - 3 23:00 до 06:00 [10, c. 19];

8) 272 злочини (67 \% у загальній структурі злочинності в УВП) вчинено злісними порушниками встановленого режиму відбування покарання (у 1997 р. - 287 (54,7\%), а ще 83 злочини (20,5 \%) - засудженими, які перебували на профілактичних обліках УВП (у 1997 р. - 27 \%) [10, с. 19]. При цьому однією з умов, що призвела до вчинення злочинів засудженими в УВП у 1997 році, стала наявність серйозних прорахунків і недоліків в організації запобіжної, соціально-психологічної, виховної та інших видів діяльності [10, с. 19]. 
Аналогічні умови, які детермінували вчинення злочинів засудженими в УВП, мали місце й у 19911997 pp. [9, с. 25-26].

у 1999 році (першому самостійному періоді функціонування ДДУПВП у системі центральних органів державної виконавчої влади [11]) засудженими в УВП вчинено 429 злочинів, що на 5,93\% більше порівняно з 1999 роком [12, с. 11]. Інші кримінологічно значущі ознаки пенітенціарної злочинності мали такий вигляд:

1) як і в попередні роки, найбільшу кількість злочинів $(167$, або 38,9 \% у загальній структурі злочинності) вчинено у виправних колоніях суворого режиму та посиленого режиму (143 злочини, або 33,3 \%) [12, с. 11];

2) рівень злочинності в розрахунку на 1 тис. засуджених склав 4 випадки, у тому числі у виправних колоніях загального режиму - 2,6 \%; посиленого - 1,56 \%; суворого - 2,42 $\%$; особливого - 2,34 \%; колоніях поселеннях - 13,1 \% [12, с. 11];

3) у звітному періоді «топографія» пенітенціарної злочинності була такою: 330 злочинів учинено в житлових зонах УВП $(76,9 \%$ у загальній їх структурі); 87 (20,3\%) - у виробничих зонах УВП; 2 (0,5 \%) - у ШІЗО; $10(2,3 \%)$ - у ПКТ.

Крім того, 384 злочини (89,5\%) вчинено з 06:00 до 18:00; 27 (6,3 \%) з 23:00 до 06:00 [12, с. 13].

У робочі дні у 1999 році вчинено 405 злочинів $(94,4 \%)$, а у святкові - 24 (5,6\%) [12, с. 13];

4) у 144 випадках $(33,6 \%)$ злочини вчинено засудженими, які перебували на профілактичних обліках УВП; у 286 випадках (66,7 \%) - порушниками режиму відбування покарання.
Суттєво не змінилися показники пенітенціарної злочинності й упродовж усього періоду самостійного функціонування ДДУПВП у системі державних органів виконавчої влади (1999-2010 рр.), тобто до повного підпорядкування органів та установ виконання покарань Міністерству юстиції України у грудні 2010 року [13]. Зокрема, у 2010 році засудженими в УВП вчинено 404 злочини (проти 422 у 2019 р.), або на 4,3 \% більше, ніж у 2010 р. [14, с. 3]. При цьому рівень злочинності в розрахунку на 1 тис. засуджених осіб упав на 8,5\% i склав у 2010 р. 3,52 випадку (у 2009 р. - 3,85), у тому числі в колоніях максимального рівня безпеки - 4,6 (у 2009 р. - 3,47\%); середнього рівня безпеки - 2,7 (у 2009 р. - 2,71); у колоніях максимального рівня безпеки із загальними умовами тримання 2,2 (у 2009 р. - 3,93); у колоніях мінімального рівня безпеки із полегшеними умовами тримання - 2,7 (у 2009 р. - 2,71); у виправних центрах 21,6 (у 2009 p. - 27,9) [14, c. 4].

Інші кримінологічні показники мали такі ознаки:

1) із 404 злочинів $290(71,8 \%$ у загальній їх структурі) вчинено засудженими в житлових зонах УВП; 67 $(16,6 \%)-$ у виробничих зонах та на контрагентських об'єктах і 47 $(11,6 \%)$ - у дисциплінарних ізолятоpax (ДІЗО) та ПКТ [14, с. 4];

2) у географічному аспекті найбільше кримінально активними були УВП Луганської, Донецької, Харківської та Хмельницької областей $[14$, c. 4];

3) у 2010 році 119 засуджених із 4,2 тис. засуджених, які перебували на профілактичних обліках УВП, учинили злочини $(2,8 \%$ у загальній їх кількості) [14, с. 5]. 
Не покращилася ситуація з означеної проблематики і у 2011 році (першому звітному році періоду часткового перебування Державної пенітенціарної служби (ДПтС) України у складі Міністерства юстиції України $[15$, с. $1-3]$.

Кількісно-якісні показники пенітенціарної злочинності в УВП залишилися незмінними як у 2012 році (час повного підпорядкування органів та установ виконання покарань Міністерству юстиції України [16], так і в подальші роки (20132016 рр.). Так, у 2016 р. (періоді активних перетворень і реформ у сфері виконання покарань [17]) кримінологічна характеристика злочинів, учинених засудженими в УВП, мала такий вигляд:

1) особами, які трималися в УВП, учинено 298 злочинів (у 2015 році - 458, або на 34,9 \% більше, ніж у 2016 році) [4, с. 1];

2) коефіцієнт злочинності в розрахунку на 1 тис. засуджених, навіть при зменшенні їх кількості порівняно з 2015 роком на $13 \%$, а з 1991 р. більше ніж на $80 \%$ [3, с. 1], у 2016 році склав 4,91 випадку (у 2015 р. $6,54)[4$, c. 6];

3) у «топографічному» вимірі злочинності найбільш кримінально активними були виправні колонії середнього рівня безпеки $(5,53$ випадку, у 2015 р. - 5,68) та максимального рівня безпеки (відповідно 4,19 та 4,06 випадку) [4, с. 2-3];

4) з точки зору «географії» злочинності пальму першості $\mathrm{y}$ 2016 році тримали УВП та СІЗО Вінницької (коефіцієнт злочинності в розрахунку на 1 тис. осіб склав 7,1); Донецької (6,7); Запорізької $(9,5)$; Кіровоградської $(8,4) ;$ Рівненської $(7,0)$; Тернопільської $(8,9)$; Херсонсь- кої $(6,1)$; Чернігівської $(6,1)$ та Чернівецької $(6,6)$ областей $[4$, с. 7].

32017 року до сьогодні, усупереч положенням основних напрямів реформування кримінально-виконавчої системи України, що затверджені Кабінетом Міністрів України ще у 1991 році [7], а також вимогам Закону України «Про Державну кримінально-виконавчу службу України» [18], Міністерство юстиції України припинило оприлюднення офіційних даних про стан і рівень злочинності в установах виконання покарань, а тому подальші закономірності їі розвитку та кримінологічно значущі ознаки встановити не вдалося.

Висновки. Отже, кримінологічний аналіз пенітенціарної злочинності в Україні за 1991-2016 pр. дозволяє зробити такі висновки:

1. Ефективність діяльності органів та установ виконання покарань із запобігання вчиненню нових злочинів засудженими в ході відбування покарань у виді позбавлення волі та обмеження волі $\epsilon$ вкрай низькою, про що свідчать кількісно-якісні показники за вказаний період. Особливо наочним прикладом у зв'язку з цим $\epsilon$ коефіцієнт злочинності (рівень учинених злочинів у розрахунку на 1 тис. засуджених, який з 1991 по 2016 роки не тільки не знизився, але й виріс із 3,9 випадку в 1991 р. до 4,91 випадку, навіть при скороченні кількості засуджених у понад 5 разів (із 156 тис. у 1991 [3, с. 1] до 48,9 тис. у 2016 p. [4, c. 1-2].

2. Однією з умов, які призводять до вчинення злочинів у сфері виконання покарань України, є неналежне інформаційне забезпечення діяльності із запобігання злочинам, у тому числі на рівні відповідних 
підрозділів Міністерства юстиції України.

3. Без кардинальної зміни організації запобіжної діяльності в УВП, налагодження їх дієвої взаємодії 3 іншими суб'єктами запобігання злочинам, а також активнішого використання при цьому можливостей кри- мінологічної характеристики злочинів неможливо якісно та результативно реалізовувати на практиці завдання та досягти мети покарання (частина перша статті 1, частина друга статті 50 КК та статті 1 і 104 КВК) щодо окремо взятого засудженого.

\section{Список використаних джерел}

1. Кримінальний кодекс України : прийнятий 5 квітня 2001 року. Відомості Верховної Ради України. 2001. № 25-26. Ст. 31.

2. Кримінально-виконавчий кодекс України : прийнятий 11 липня 2003 року. Відомості Верховної Ради України. 2004. № 3-4. Ст. 21.

3. Некоторые показатели деятельности учреждений уголовноисполнительной системы МВД Украины в 1991 году. Информ. бюллетень. Киев : ГУИН МВД Украины, 1992. 28 с.

4. Про стан правопорядку, ізоляції та нагляду, діяльність підрозділів охорони, пожежної безпеки та воєнізованих формувань Державної кримінально-виконавчої служби України у 2016 році : Інформ. бюлетень. Київ : Департамент ДКВС Міністерства юстиції України, 2017. 34 с.

5. Корупційні та інші злочини, що вчиняються у сфері виконання покарань: кримінологічна характеристика та запобігання : навч. посібник / за ред. д. ю. н., проф. О. Г. Колба. Київ : Видавничий дім «Кондор», 2019. 444 с.

6. Кримінологія : підручник / В. В. Голіна, Б. М. Головін, М. Ю. Валуйська та ін.; за ред. В. В. Голіни, Б. М. Головіна. Харків : Право, 2014. 440 с.

7. Основные направления реформ уголовно-исполнительной системы в Украинской ССР : утверд. постановлением Кабинета Министров Украинской ССР от 11.07.1991 г. № 88. Киев : ГОУИН МВД Украинской ССР, 1991. 18 с.

8. Про утворення Державного департаменту України з питань виконання покарань : Указ Президента України від 22 квітня 1998 р. № 344/98. Урядовий кур'єр. 1998. № 82-83. Ст. 114.

9. Оперативно-службова і виробничо-господарська діяльність органів i установ виконання покарань України у 1997 році: Інформ. бюлетень. Київ : ГУВП МВС України, 1998. № 20.113 с.

10. Оперативно-службова i виробничо-господарська діяльність органів i установ виконання покарань України у 1998 році : Інформ. бюлетень. Київ : ДДУ ПВП, 1999. № 2.83 c.

11. Про виведення Державного департаменту України з питань виконання покарань з підпорядкування МВС України : Указ Президента України від 12 березня 1999 року. № 248/99. Офіційний вісник України. 1999. № 11. Ст. 24.

12. Оперативно-службова та виробничо-господарська діяльність органів i установ виконання покарань України у 1999 році : Інформ. бюлетень. Київ : ДДУ ПВП, 2000. № 4.84 c.

13. Про оптимізацію системи центральних органів виконавчої влади : Указ Президента України від 9 грудня 2010 року. Офіційний вісник України. 2010. № 94. Ст. 33-34. 
14. Про діяльність підрозділів охорони, нагляду і безпеки кримінальновиконавчих установ у 2010 році : Інформ. бюлетень. Київ : ДПтС України, 2011. 67 с.

15. Про діяльність підрозділів охорони, нагляду і безпеки кримінальновиконавчих установ у 2011 році : Інформ. бюлетень. Київ : ДПтС України, 2011. 69 с.

16. Про внесення змін і доповнень у закони, що стосуються виконання кримінальних покарань : Закон України від 16.10.2012 р. № 5461-VI. Відомості Верховної Ради України. 2014. № 5. Ст. 62.

17. Про ліквідацію територіальних органів управління Державної пенітенціарної служби та утворення територіальних органів Міністерства юстиції : постанова Кабінету Міністрів України від 18 травня 2016 року № 348. Офіційний вісник Украӥни. 2016. № 44. Ст. 388.

18. Про Державну кримінально-виконавчу службу України : Закон України від 23 червня 2005 року. Офіційний вісник України. 2005. № 30. Ст. 174.

\section{References}

1. Kriminalnij kodeks Ukrayini (2001). Vidomosti Verhovnoyi Radi Ukrayini, 25-26, 31 [in Ukrainian].

2. Kriminalno-vikonavchij kodeks Ukrayini (2003). Vidomosti Verhovnoyi Radi Ukrayini. 2004, 3-4, 21 [in Ukrainian].

3. Nekotorye pokazateli deyatelnosti uchrezhdenij ugolovno-ispolnitelnoj sistemy MVD Ukrainy v 1991 godu. Inform. byulleten. Kiev: GUIN MVD Ukrainy, 1992 [in Ukrainian].

4. Pro stan pravoporyadku, izolyaciyi ta naglyadu, diyalnist pidrozdiliv ohoroni, pozhezhnoyi bezpeki ta voyenizovanih formuvan Derzhavnoyi kriminalno-vikonavchoyi sluzhbi Ukrayini u 2016 roci: Inform. byuleten. Kiyiv: Departament DKVS Ministerstva yusticiyi Ukrayini, 2017 [in Ukrainian].

5. Kolb, O. G. (Red.). (2019). Korupcijni ta inshi zlochini, sho vchinyayutsya u sferi vikonannya pokaran: kriminologichna harakteristika ta zapobigannya : navch. posibnik. Kiyiv: Vidavnichij dim «Kondor» [in Ukrainian].

6. Golina, V. V., Golovin, B. M. \& Valujska, M. Yu. (2014). Kriminologiya : pidruchnik. Harkiv: Pravo [in Ukrainian].

7. Osnovnye napravleniya reform ugolovno-ispolnitelnoj sistemy v Ukrainskoj SSR : utverd postanovleniem Kabineta Ministrov Ukrainskoj SSR ot 11.07.1991 g. № 88. Kiev: GOUIN MVD Ukrainskoj SSR, 1991 [in Russian].

8. Pro utvorennya Derzhavnogo departamentu Ukrayini z pitan vikonannya pokaran: Ukaz Prezidenta Ukrayini (1998). № 344/98. Uryadovij kur'yer, 82-83, 114 [in Ukrainian].

9. Operativno-sluzhbova i virobnicho-gospodarska diyalnist organiv i ustanov vikonannya pokaran Ukrayini u 1997 roci: Inform. byuleten. Kiyiv: GUVP MVS Ukrayini, 1998. № 20. [in Ukrainian].

10. Operativno-sluzhbova i virobnicho-gospodarska diyalnist organiv i ustanov vikonannya pokaran Ukrayini u 1998 roci: Inform. byuleten. Kiyiv : DDU PVP, 1999. № 2. [in Ukrainian].

11. Pro vivedennya Derzhavnogo departamentu Ukrayini z pitan vikonannya pokaran z pidporyadkuvannya MVS Ukrayini: Ukaz Prezidenta Ukrayini vid 12 bereznya 1999 roku. № 248/99. Oficijnij visnik Ukrayini, 1999, 11, 24 [in Ukrainian].

12. Operativno-sluzhbova ta virobnicho-gospodarska diyalnist organiv i ustanov vikonannya pokaran Ukrayini u 1999 roci: Inform. byuleten. Kiyiv: DDU PVP, 2000. № 4 [in Ukrainian].

13. Pro optimizaciyu sistemi centralnih organiv vikonavchoyi vladi: Ukaz Prezidenta Ukrayini vid 9 grudnya 2010 roku. Oficijnij visnik Ukrayini. 2010, 94, 33-34 [in Ukrainian]. 
14. Pro diyalnist pidrozdiliv ohoroni, naglyadu i bezpeki kriminalno-vikonavchih ustanov u 2010 roci: Inform. byuleten. Kiyiv: DPtS Ukrayini, 2011 [in Ukrainian].

15. Pro diyalnist pidrozdiliv ohoroni, naglyadu i bezpeki kriminalno-vikonavchih ustanov u 2011 roci: Inform. byuleten. Kiyiv: DPtS Ukrayini, 2011 [in Ukrainian].

16. Pro vnesennya zmin i dopovnen $\mathrm{u}$ zakoni, sho stosuyutsya vikonannya kriminalnih pokaran : Zakon Ukrayini vid 16.10.2012 r. № 5461-VI. Vidomosti Verhovnoyi Radi Ukrayini. 2014, 5, 62 [in Ukrainian].

17. Pro likvidaciyu teritorialnih organiv upravlinnya Derzhavnoyi penitenciarnoyi sluzhbi ta utvorennya teritorialnih organiv Ministerstva yusticiyi: postanova Kabinetu Ministriv Ukrayini (18 travnya 2016) № 348. Oficijnij visnik Ukrayini. 2016, 44, 388 [in Ukrainian].

18. Pro Derzhavnu kriminalno-vikonavchu sluzhbu Ukrayini: Zakon Ukrayini (23 chervnya 2005). Oficijnij visnik Ukrayini, 2005, 30, 174 [in Ukrainian].

T. Popelnyuk, Postgraduate Student of the Eastern-Europe National University them Lesia Ukrainka

\section{About criminological characteristic of crimes, that are made in the sphere of execution of punishments of Ukraine}

One of the tasks and, at the same time, the elements of the purpose of punishment in the current criminal case (Part 1 of Article 1 and Part 2 of Article 50 of the Criminal Code (hereinafter referred to as the Criminal Code)) and the Criminal Executive (Part 1 of Article 1 and Part 1 of Article 104 of the Criminal Enforcement Code (KVC), the legislation of Ukraine stipulates the prevention of crimes by both convicted persons and others. However, starting from 1991 to the present, annually, the crime rate in the sphere of punishment of Ukraine has a steady upward trend (from 3.9 crimes per 1 thousand convicts in 1991 to 4.91 - in 2016).

At the same time, one of the circumstances that adversely affects the organization of crime prevention activities in the institutions of execution of penalties (PEC), is insufficient information support of this process, which is based on the criminological characteristics of crimes, which is derived at the doctrinal level and is of practical importance.

Therefore, there is a complex applied problem that needs urgent solution, including at the scientific level, which led to the choice of the topic of this article, and also determined its main task - to prove the need for a more active and effective use in practice of the theoretical model of criminological characteristics of crimes in order to improve the legal mechanism of preventive action in the sphere of punishment of Ukraine.

Keywords: criminological characteristics; convicted; the crime; imprisonment; penal institutions; crime prevention; penitentiary personnel.

Надійшла до редакції 05.08.2019

(C) Попельнюк Т. В., 2019 